\title{
The Legal Regime of Noise Pollution in Nigeria
}

\author{
Hakeem Ijaiya \\ Department of Private and Property Law, Faculty of Law, University of Ilorin, Ilorin, Nigeria \\ Email: hakeemijaiya@yahoo.com, hakeemijaiya@mail.com
}

Received 5 November 2013; revised 3 December 2013; accepted 2 January 2014

Copyright (C) 2014 by author and Scientific Research Publishing Inc.

This work is licensed under the Creative Commons Attribution International License (CC BY). http://creativecommons.org/licenses/by/4.0/

(c) (i) Open Access

\begin{abstract}
Man is born with noise and dies with that, thus noise is part of human life and a natural product of human environment. Noise like smog, is a slow agent of death. Noise may not appear as a threat to global environment on the same level as deforestation, hazardous wastes or emission of poisonous gases into the atmosphere but if it continued the next 30 years as it has for the last 30 years, it could become lethal. Against this background, this paper examines noise as a factor harmful to the environment with focus on Nigeria. The paper looks at noise pollution in Nigeria and the legal regime relating to the problem. The paper examines how environmental law and other relevant sources of law endeavoured to tackle noise pollution in the country.
\end{abstract}

\section{Keywords}

Noise; Pollution; Environment

\section{Introduction}

Noise consists of sound, which is transported by air (Okorodudu-Fubara, 1998). Noise is not inherently harmful to the human or environment. ${ }^{1}$ It is when noise becomes unusually loud and uncontrolled that it diminishes the quality of air and adversely affects the environment, public health and welfare. ${ }^{2}$ Pollution is the introduction of contaminants into the natural environment that causes adverse change, instability, disorder, harm or discomfort to the ecosystem i.e. physical systems or living organism. ${ }^{3}$ Pollution can take the form of chemical substances or

\footnotetext{
${ }^{1}$ The word noise is derived from Latin term "nausa”. It may be defined in law as "excessive, offensive, persistent or startling sound".

${ }^{2}$ Based on studies, noise becomes offensive and unhealthy when it goes beyond certain limit, with the prescribed limit set at 95 decibels. Noise is a pollutant which produces a contaminated environment which becomes a nuisance and affects the health of a person, his activities and mental abilities.

${ }^{3}$ There are two major causes of pollution, natural and manmade. Natural Pollution occurs naturally and does not cause excessive harm to our lives due to its regenerated ability. While the manmade pollution is caused by human activities, and are hard to get rid of, the backbones of manmade pollution are the human population and technology.
} 
energy, such as noise, ${ }^{4}$ heat or light. ${ }^{5}$ Noise pollution is one of the environmental hazards affecting humans as well as climate. ${ }^{6}$ In most urban areas of the third or developing countries of the world especially Nigeria, there are lots of noise pollutants which include noise from exhaust cars, industrial as well as home generating plants. In advanced countries however, scientific experimentations like launching and re-lunching of rockets, bombs and satellites sounds constitutes a major climate pollutant (Kapoor \& Singh, 1995; Nagi, Dhillon, \& Dhlwat, 1999). Against this background, this paper examines noise as a factor harmful to the environment with focus on Nigeria. The paper looks at noise pollution in Nigeria and the legal regime relating to the problem. The paper examines how environmental law and other relevant sources of law endeavoured to tackle noise pollution in the country.

\section{Sources of Noise Pollution}

The main sources of noise pollution in Nigeria are electricity generating plants, vehicular traffic noise engine and pressure horns, construction/industrial noise, machinery noise, noise from religious worship, institutions and household noise.

\subsection{Electricity Generating Plants}

Electric energy occupies the top grade in energy hierarchy as it is in innumerable use in homes, industries, agriculture, and for transportation purpose. Nigeria's electricity power situation is very poor because of erratic power supply (Akinbulire, Oluseyi, Awosope, \& Okoro, 2008). There is an upsurge in the use of electricity generating plant with its attendant noise pollution on the environment and human health. Most workplaces and homes use generating plants 24 hours in alternative to power supply. ${ }^{7}$

\subsection{Vehicular Traffic Noise Engine and Pressure Horns}

Increase in vehicular traffic and engine noise is a major source of noise pollution in most urban cities in Nigeria. The situation is alarming with increase in traffic density in the cities. ${ }^{8}$ The emissions of smoke from cars are of great concern to the changes in climate.

\subsection{Construction/Industrial Noise}

The construction of buildings, highways and city streets causes a lot of noise. Pneumatic hammers, air compressors, bulldozers, loaders, dump trucks and pavement breakers are the major sources of noise pollution in construction sites.

\subsection{Machinery Noise}

Motors and compressors used in the industries create a lot of noise which adds to the detrimental state of noise pollution in Nigeria. Plumbing, boilers, generators, air conditioners and fans creates a lot of noise in the buildings and add to the prevailing noise pollution (Despak, 2009).

\subsection{Noise from Religious Worship Institutions}

Nigeria is a multi-religious society and is therefore prone to religious activities. These congregational worships are held in mosques, churches and other nonconventional areas like residential and workplaces, in day time and

\footnotetext{
${ }^{4}$ Noise pollution encompasses roadway noise, aircraft noise, industrial noise as well as high-intensity sonar.

${ }^{5}$ Light pollution includes light trespass, over illumination and astronomical interference. Other form of pollution includes littering, radioactive contamination, water pollution and pollution caused by natural disaster such as hurricanes.

${ }^{6}$ Though not physically visible, noise has been a major catalyst to climate change and practical sources of human health catastrophes globally.

${ }^{7}$ The noise from generating plants in Nigeria coupled with its accompanying emission of smoke into the sky has greatly contributed to ozone layer depletion.

${ }^{8}$ There is astronomical increase in rural-urban migration in Nigeria. A significant of urban populace use motorized transportation. The noise generated from there is enormous as to affect human health. Due to economic downturn in the Nigerian economy, it became increasingly difficult for Nigerians to purchase new vehicles. The norm is to resort to second hand vehicles imported from different countries. Expectedly the engine and other conditions of such vehicles make them to generate more noise than new vehicles.
} 
even throughout the night. ${ }^{9}$

\subsection{Household Noise}

Household equipments such as vacuum cleaners, mixers and some kitchen appliances are noise makers of the house. ${ }^{10}$ Also noise can be generated from neighborhood. ${ }^{11}$

\section{Effects of Noise Pollution}

Noise Pollution has ill effects on human beings on well as other living and non-living things.

\subsection{Effects of Noise Pollution on Human Health}

Noise damages the ear and causes temporary or permanent noise induced hearing loss. Auditory effects may lead to temporary hearing loss ${ }^{12}$ or permanent hearing loss.

Many people complain that noise makes them mentally ill. ${ }^{13}$ Doctors and scientists have now medically confirmed that noise disturbs the biological organisms and their respective functions of the humans. Five crackers and other excessive and continuous explosives become physically painful giving rise to neurosis, mental illness, cardiovascular diseases, stomach ulcers and respiratory disorders reducing human life (Kaur, 2007).

Psychiatrists and psychologists have recently observed that noise has certain relation with physical health causing tension resulting in problems such as speech interference, annoyance, fatigue, sleep interference and emotional distress. Noise levels in industries causes interference in efficiency and communication and raises possibilities of accidents.

\subsection{Effects on Animals and Other Living Things}

The effect caused by industries, railways, explosions and commotion in the cities, aircrafts etc can be felt on animals and birds. ${ }^{14}$ Noise emissions caused by supersonic aircraft, railway noise emissions etc may cause miscarriage in mammals, fishes and birds.

Intense noise levels also affect non-living things too. The sonic booms cause cracks in national and archeological monuments as well as very high levels of noise are the cause of crackes in hills. High intensity explosions can break glass panes and vibrations in buildings.

\section{Statutory Provisions of Noise Pollution in Nigeria}

The legal regime on Noise Pollution in Nigeria can be considered under two main headings. The common law and the policy and statutes:

\footnotetext{
${ }^{9}$ Nigeria has been undergoing a religious renaissance, which, among others, manifests in congregational worships in various forms, especially by Pentecostal Christian groups, Congregational worships are held in different places including residential areas, in the daytime and throughout the night. Noise of significant levels are generated from these congregational worships with the use of heavy public address systems and intensity of the voices of the worshippers oozing from inside. Despite the thunderous nature of the noise and its adverse effect on human health, the government has shield away from addressing the issue. For example, a Bill to control noise emission from religious places in Lagos and Kwara States was met with strong opposition and eventually, the idea was dropped, but Lagos State has been serious in controlling noise pollution levels in the state especially in religious houses through their environmental agency.

${ }^{10}$ Though they do not cause much problem, their effect on human health cannot be neglected.

${ }^{11}$ Noise pollution from neighboring apartment and noise within one's own apartment. Another causes of noise pollution is Honking Noise. Some people while honking, do not realize the inconveniences they cause others and themselves. There could be hearing difficulties, stress level may go high and also mental instability. Honking unnecessarily while driving or stationed in a place has become a trend these days and one can hear it very well at the traffic signals. Goods are advertised and sold in vehicle using loud speaker even in promoting goods and services, Loud speakers are used by transporters to invite intending travelers.

${ }^{12}$ The temporary hearing loss is a physiological phenomenon, which is reversible. Temporary loss of hearing occurs when the ear is exposed for a short duration to excessive noise or when the ear is exposed to the noise at damaging intensities for sufficiently long period of time. Sudden noise is more harmful than continuous one. The hearing limit of noise in man is about $140 \mathrm{~dB}$. Human ears feel fatigue if exposed to over $80 \mathrm{~dB}$ for more than half an hour. It causes temporary deafness if the loudness of the noise is $100 \mathrm{~dB}$. It is painful at $140 \mathrm{~dB}$.

${ }^{13}$ If the intensity and the duration of the noise is high then it leads to permanent loss of hearing. It is an irreversible loss of hearing and it is caused by either prolonged noise exposure of high intensity noise or it may be caused when the intensity of the noise is more than $140 \mathrm{~dB}$. When a stage is reached at which hearing loss no longer returns to its original level, it is called noise induced hearing loss or permanent threshold shift.

${ }^{14} \mathrm{Birds}$ avoid migrating to places where noise level is above $100 \mathrm{~dB}$.
} 


\subsection{Common Laws}

Statutory intervention on the issue of noise pollution in Nigeria can be considered from the common law perspective. The common law intervention is through the actionable tort of nuisance. ${ }^{15}$ Through a court action for nuisance, an aggrieved person can obtain damages for injury suffered from the offensive noise and also injunction to stop any further emission of such noise. ${ }^{16}$ In Abiola vs. Ijoma, ${ }^{17}$ the plaintiff and the defendant were neighbours occupying adjoining premises in a residential area. The plaintiff kept poultry at the back of his house. At a time the defendant kept four hundred chickens in pens erected against a wall that constituted the boundary with the plaintiff. The plaintiff contended among other claims, excessive noise made by defendant's chickens in the early hours of the morning that disturbed his sleep. The court agreed with the plaintiff and awarded damages against the defendant for nuisance. The court also made an order of injunction restraining the defendant from further acts of nuisance. ${ }^{18}$

In Tebite vs. Marine and Trading Co. Ltd. ${ }^{19}$ The plaintiff, a legal practitioner occupied premises where he carried out his law practice. The defendants occupied adjourning premises where they carried out the business of boat building and repairing. The plaintiff sued contending principally that by operating its machines continuously for several hours a day the defendants had persistently caused the emission of loud and excessive noise and noxious fumes from their premises which caused the plaintiff much discomfort and inconvenience. It was established in the course of the proceedings that the noise generated and emitted by the defendants was excessive and much more than any noise that can be produced in any noisy area in Nigeria. The court held that the noise was excessive and awarded damages to the plaintiff and also restrained the defendants from further act of noise nuisance.

In Moore vs. Nnado. ${ }^{20}$ The plaintiff sued contending that the defendant was caused excessive to be emitted from his neighbouring by playing music unreasonably loudly until late every night. The court held that the defendant liable to the plaintiff. The court also granted the order of injunction restraining the defendant from the said act of nuisance.

However the common law remedy through court action does not offer a comprehensive and infallible solution to noise pollution in Nigeria as a result of some inherent socio-economic factors. One of such factor is the high cost of legal fees and the frustration of forensic battles in Nigeria where the adversary system of justice system is operated (Oyelade, 2007). Another factor is the traditional inclination of Nigerians to avoid legal confrontation with neighbours or other people. Taken together, the likely result of these inherent factors is that many citizens may shy away from instituting court action to confront noise pollution even where they are directly affected (Odunsi \& Ogunlade, 2007).

\subsection{Policy and Statutes}

Looking to the serious and disastrous effects of noise pollution on human life, it is essential to take preventive and protective measures. There is no doubt; the Nigerian government has taken bold steps to curtail noise especially in the cities. As regards the statutory control of noise, it is surprising that there exists no law under the Nigerian legal system exclusively, dealing with the problem of noise or its control.

Nigeria does not have specific legislations on noise pollution as is the case in countries like the United States of America and United Kingdom. The relevant policies on noise pollution are:

1) The National Environmental Standards and Regulations Enforcement Agency (Establishment) Act.

The National Environmental Standards and Regulations Enforcement Agency (Establishment) Act of 2007 is the major law on noise pollution in Nigeria. The law ${ }^{21}$ provides that:

\footnotetext{
${ }^{15}$ Samoris vs Maja (1996) 7 NWLR (pt. 460) p. 336. The tort of nuisance can be explained as the unlawful interference with a person’s use or enjoyment of his property by another person. It can manifest in the form of noise, vibration, smoke, fume, smell, pollution, flooding, fire etc.

${ }^{16}$ Luxmoore J. in Vandepant v. Mayfair Hotel Co. Ltd (1930) 1 Ch. 138 recognizes the inevitability of some discomfort arising from noise in that it interferes with health enjoyment of the environment.

${ }^{17}(1970) 2$ ALL NLR 268

${ }^{18}$ An effective remedy to combat noise pollution lies in the court. However, while legal action for nuisance is a potent means of confronting noise pollution in Nigeria, the use of this devise may be hampered by some legal factors which are the legal classification of nuisance into public and private nuisance.

${ }^{19}(1971)$ I UILR 432

${ }^{20}(1967)$ FNLR 156

${ }^{21}$ Section 22 National Environmental Standards and Regulation Enforcement Agency (Establishment) Act, 2007.
} 
a) The Agency shall on the commencement of this Act, and in consultation with appropriate authorities:

i) identify major noise sources, noise criteria and noise control technology; and

ii) make regulations on noise, emission control, abatement, as may be necessary to preserve and maintain public health and welfare.

b) The Agency shall enforce compliance with existing regulations and recommend programs to control noise originating from industrial, commercial, domestic, sports, recreational, transportation or other similar activities.

2) National Policy on the Environment and Noise Pollution.

The National policy on the Environment of $1988^{22}$ provided that programmes will be established to:

a) set up standards including acoustic guarantees;

b) prescribe guidelines for the control of neighbourhood noise especially with respect to construction sites, market and meeting places.

c) prescribe permissible noise level in noise-prone industries and construction sites and to ensure the installation of noise dampers on noise equipment;

d) set up quiet zones especially within game parks, reserves and recreational centres;

e) ensure compliance with stipulated standards by conducting periodic audit checks.

3) National Environmental Protection (Pollution Abatement in Industries and Facilities Generating Wastes) Regulations and Noise Pollution.

The National Environmental Protection (Pollution Abatement in Industries and Facilities Generating Wastes) Regulation of 1991 enjoined designated industrial layouts separate from residential areas and to create buffer zones separating industrial areas from residential areas. ${ }^{23}$

4) National Guideline and Standards for Environmental Pollution Control in Nigeria.

The National Guidelines and Standards for Environmental Pollution Control in Nigeria of 1991 were meant to monitor and control industrial and urban pollution.

\section{Other Jurisdiction}

\subsection{United States of America}

The passage of the National Environmental Policy Act (NEPA) ${ }^{24}$ and the Noise Pollution and Abatement Act ${ }^{25}$ is a remarkable step toward eradicating noise pollution in USA. ${ }^{26}$ There are also state laws; ${ }^{27}$ many cities throughout USA have noise ordinances, which specify the allowable, sound level that can cross property lane. These ordinances can be enforced with local police powers. ${ }^{28}$

\subsection{Europe}

Several European countries such as Netherlands, France, Spain and Denmark emulated the USA noise control law. The EU enacted regulations geared towards curbing noise pollution for example the EU Environmental Noise Directives ${ }^{29}$ empowered EU to identity noise pollution levels and to trigger the necessary action both at member state and EU level.

\subsection{India}

Noise Pollution is a major problem in India especially during festivals of Diwali, Navaratri and Ganpati. The Government of India has regulations against fire crackers and loudspeakers. ${ }^{30}$ Awaaz foundation is an Indian NGO working to control noise pollution from various sources in Mumbai through advocacy, public interest litigation

\footnotetext{
${ }^{22}$ Paragraph 3.12

${ }^{23}$ Regulation 12(1) a and b National Environmental Protection (Pollution Abatement in Industries and Facilities Generating Wastes) Regulations of 1991.

${ }^{24} 1969$ NEPA requires all federally founded major actions to be analyzed for all physical environment impacts including noise pollution.

${ }^{25}$ 1972, commonly called the Noise Control Act (NCA) 1972. NCA directed EPA to promulgate regulations for a host of noise emission.

${ }^{26}$ Before the passage of the NEPA and NCA few people in USA recognized that citizens are entitled to protection from adverse sound level exposure.

${ }^{27}$ For example, California has a Noise Element of the General plan, substantial noise data base and blueprint. The Noise Element became an integral part of the municipal or country General Plan.

${ }^{28}$ Noise Pollution Clearinghous, Montpelier, TV Noise Regulations and Ordinances of US Cities, Countries and Towns.

${ }^{29}(2002 / 49 /$ EC)

${ }^{30}$ Government of India: Central Pollution Control Board FAQs
} 
awareness and educational campaigns since 2003. Under Environmental Protection Act, 1966 India equally established Noise Pollution Control Rules, 2000 in order to curb the growing problem of noise pollution. ${ }^{31}$

\section{Conclusion}

The challenges posed by noise pollution on human health and the environment have not received full attention which they deserve. Generally statutory and policy provisions regulating noise pollution in Nigeria as well as other countries examined have lofty aims and are quite salutary, there is however the need for proper implementation. ${ }^{32}$ Considering the adverse effects of noise pollution on human health and the environment, it is proper to evolve proper approaches to address the issue of noise and protection of human and environmental health in Nigeria. ${ }^{33}$ The government should put in place regulatory agency that will assist in the measurement, control and enforcement of laws to achieve a desired goal. There is the need to take advantage of the opportunities presented to man by technological advancement in the area of measurement and control of noise through the use of gargets like insulator and sound proofing to doors, walls, ceilings, using ear protection and zoning urban area to maintain a separation between residential area and zones of excessive noise (Alawode, Stephen, \& Adeyemi, 2008). There is the urgent need for review or strategic assessments of government policies, plans and programmes for noise pollution and environmental health. ${ }^{34}$ Finally there is a need for public enlightenment, education and sensitization on the hazards, dangers and human health problems to be associated with noise pollution.

\section{References}

Akinbulire, P. O., Oluseyi, P. O., Awosope, C. O. A., \& Okoro, O. O. (2008). Data-Based Analysis of Power System Crisis in Nigeria. ESPTAEE 2008 National Conference, University of Nigeria, Nsukka, 25-27 June 2008, 190-195.

Alawode, A. J., Stephen, J. T., \& Adeyemi, G. T. (2008). Health, Safety and Environmental Issues in Nigerian Manufacturing and Processing Industries. Journal of Engineering and Applied Sciences, 3, 634-641.

Asein, J. O. (2005). Introduction to Nigerian Legal System. Lagos: Ababa Press Ltd.

Despak, M. (2009). Noise Pollution, Sources, Effect and Control.

Kapoor, B. S., \& Singh, K (1995). Noise the Insidious Killer. The Tribune, 25 November, 1995.

Nagi, G. K., Dhillon, M. K., \& Dhlwat, G. S. (1999). Noise Pollution (p. 5). New Delhi: Common Wealth Publishers.

Odunsi, B., \& Ogunleye, T. A. (2007). Noise Pollution and Environment: The Nigerian Perspective. 5th International Conference on International Environmental Law, New Delhi, 8-9 December, 2007.

Okorodudu-Fubara, M. T. (1998). Law of Environmental Protection. Materials and Text, Ibadan: Ibadan Caltop Publication Ltd.

Oyelade, O. S. (2007) Conflict Resolution and Human Rights in Traditional African Society JIL, 45.

\footnotetext{
${ }^{31}$ Causes and Effects of Noise Pollution, www.lifesty.iloveindia.com Chapter iv of the Indian Penal Code particularly Sections 268, 269, 270 280, 291 and 294 deal with offences relating to public health safety, decency etc.

${ }^{32}$ However, since Nigeria is yet to be a super power or neck deep into launching of rockets, bomb or other scientific experimentation that could result in hyper climate change, aggressive implementation of the existing laws, policies and guidelines on environmental pollution will go a long way in addressing the problem of noise pollution and its resultant effect of climate change in Nigeria.

${ }^{33}$ The National Assembly should pass a bill making it mandatory for all states and local government of the federation to enact similar law to combat noise pollution in Nigeria.

${ }^{34}$ Strict punishment is recommended for any breach of environment laws in Nigeria.
} 